P-ISSN 2442-6636

E-ISSN 2355-3987

www.ijhn.ub.ac.id

Artikel Hasil Penelitian

\title{
Kebiasaan Sarapan Berhubungan dengan Tingkat Kebugaran Jasmani pada Anak Usia Sekolah Dasar di SD Budya Wacana Yogyakarta
}

\author{
Ave Maria Rosario ${ }^{1}$, Yoseph Leonardo Samodra ${ }^{1 *}$, Yanti Ivana Suryanto ${ }^{1}$ \\ ${ }^{1}$ Fakultas Kedokteran Universitas Kristen Duta Wacana Yogyakarta \\ *Alamat korespondensi: Email: yoseph_samodra@staff.ukdw.ac.id , Telp: 0274-563929, Fax: 0274-8509590
}

Diterima: Juni 2019

Direview: Juni 2019

Dimuat: Desember 2019

\begin{abstract}
Abstrak
Di Indonesia terdapat $40 \%$ anak yang melewatkan sarapan. Melewatkan sarapan dapat memengaruhi penurunan aktivitas fisik. Kurangnya aktivitas fisik ini berdampak pada penurunan kebugaran jasmani, sehingga seseorang akan lebih mudah lelah dan kurang optimal dalam melakukan aktivitas harian. Penelitian ini bertujuan untuk mengetahui hubungan antara kebiasaan sarapan dengan tingkat kebugaran jasmani pada anak usia sekolah dasar di SD Budya Wacana Yogyakarta. Penelitian menggunakan metode cross sectional dengan subjek penelitian adalah anak usia sekolah dasar kelas IV, V, dan VI di SD Budya Wacana Yogyakarta, yang diambil dengan metode total sampling, yaitu sebesar 157 siswa. Pengambilan data menggunakan kuisioner sarapan dan tingkat kebugaran jasmani dengan lari jarak menengah (1000 meter). Analisis statistik menggunakan spearman rank, dengan tingkat kepercayaan 95\%. Hasil analisis menunjukkan terdapat hubungan antara kebiasaan sarapan dengan tingkat kebugaran jasmani $(\mathrm{p}=0.023)$, serta adanya hubungan antara status gizi dengan tingkat kebugaran jasmani $(\mathrm{p}=0.000)$. Tidak terdapat hubungan antara jenis kelamin $(\mathrm{p}=0.682)$, usia $(\mathrm{p}=0.021)$, penyakit kardiovaskular respirasi $(\mathrm{p}=0.781)$ dengan tingkat kebugaran jasmani. Hasil analisis multivariat dengan uji regresi logistik hubungan status gizi $(\mathrm{p}=0.000)$ dengan tingkat kebugaran jasmani memiliki hubungan yang lebih besar dibandingkan dengan kebiasaan sarapan $(\mathrm{p}=0.011)$. Status gizi dapat mempengaruhi $11,9 \%$ dari kebugaran jasmani siswa dalam penelitian ini.
\end{abstract}

Kata kunci: Kebugaran Jasmani, Kebiasaan Sarapan, Status Gizi, Usia Sekolah Dasar

\begin{abstract}
Globally, linear growth failure is the most common form of childhood malnutrition, with around In Indonesia there are $40 \%$ of children who skip breakfast and it can reduce their physical activity. This lack of physical activity will decrease physical fitness, thus someone will be easily tired and non-optimal doing their daily activities. This research aimed to find out the correlation between breakfast habits and physical fitness levels among elementary school-age children at Budya Wacana Elementary School Yogyakarta. The study used cross sectional method and total sampling technique, with 157 students come from IV, V, and VI grades as the subjects. The data were collected using a breakfast questionnaire, as well as physical fitness level with medium distance running (1000 meters). Spearman Rank was used for bivariate analysis, with a confidence level of 95\%. The results showed that there was a correlation between breakfast habits and nutritional status with physical fitness level in about $p=0.023$ and $p=0.000$, respectively. Moreover, there was no correlation between gender $(p=0.682)$, age $(p=0.021)$, cardiovascular respiration disease $(p=0.781)$ with physical fitness level. From the results of multivariate analysis with
\end{abstract}


logistic regression test the nutritional status has a greater correlation $(p=0.000)$ with physical fitness level than breakfast habits $(p=0.011)$. Therefore, this research showed that nutritional status affected in about 11,9\% of students' physical fitness.

Keywords: Physical Fitness, Breakfast Habits, Nutritional Status, Elementary School Age

\section{PENDAHULUAN}

Penurunan aktivitas fisik berdampak pada penurunan kebugaran jasmani. Kebugaran jasmani secara umum didefinisikan sebagai kemampuan tubuh untuk melakukan kegiatan sehari-hari dengan efektif dan efisien tanpa rasa lelah. Untuk menghasilkan kebugaran jasmani diperlukan komponen-komponen tubuh yang optimal, hal ini dapat diperoleh dengan berolahraga atau latihan fisik. Kebugaran jasmani mempengaruhi kualitas hidup yang memberikan dampak positif bagi kesehatan, serta bagi olahragawan dapat menunjang keterampilan dalam olahraga. ${ }^{1}$ Berbagai faktor dapat mempengaruhi tingakat kebugaran jasmani seperti usia, jenis kelamin, genetik, aktivitas fisik, lingkungan, kemampuan fungsi kardiovaskular dan respirasi, status gizi, kebiasaan membantu mengisi energi yang merokok, alkohol, manajemen stress, serta kebutuhan nutrisi harian. Setiap aktivitas fisik harian maupun olahraga, tubuh sangat memerlukan energi. Energi didapatkan dari asupan nutrisi harian melalui sarapan pagi. Sarapan sudah digunakan ketika tidur tubuh membakar kalori untuk meperbaharui sel dan metabolisme tubuh. $^{2}$ Anak usia sekolah yang memiliki kebiasaan sarapan akan meningkatkan kinerja belajar di sekolah, serta meningkatkan kognitif anak. Namun di Indonesia masih banyak anak yang tidak terbiasa sarapan, sehingga aktivitas di sekolah dapat menjadi tidak optimal. ${ }^{3}$

\section{METODE PENELITIAN \\ Rancangan/Desain Penelitian}

Penelitian ini menggunakan jenis penelitian observasional analitik, dengan pendekatan cross-sectional. Dilakukan pada bulan Januari 2019, di SD Budya Wacana Yogyakarta.

\section{Sasaran Penelitian}

Sasaran pada penelitian ini adalah siswa siswi kelas IV, V, dan VI SD Budya Wacana Yoogyakarta dengan menggunakan metode total sampling. Di dapatkan jumlah subjek yang telah memenuhi kriteria inklusi dan eksklusi sebesar 157 subjek.

\section{Teknik Pengumpulan Data}

Pengambilan data menggunakan kuisioner yang berisi pertanyaan kebiasaan sarapan, screening adanya penyakit kardiovaskular dan respirasi, usia, jenis kelamin. Selain itu dilakukan juga pengukuran status gizi. Pada penilaian tingkat kebugaran jasmani menggunakan tes lari jarak menengah 1000 meter atau single test untuk usia anak sekolah dasar.

\section{Teknik Analisis Data}

Penelitian ini menggunakan analisis bivariat spearman rank untuk mengetahui korelasi variabel bebas, dan variabel perancu terhadap variabel terikat serta menggunakan analisis multivariat uji regresi logistik untuk mengetahui variabel yang paling berpengaruh terhadap variabel terikat.

\section{HASIL PENELITIAN}

Frekuensi jenis kelamin tertinggi yaitu perempuan 89 subjek (56.7\%) 
sedangkan laki-laki 68 subjek (43.3\%). Usia subjek penelitian didapatkan frekuensi diusia 8 tahun 2 subjek (1.3\%), 9 tahun sebesar 51 subjek
(32.5\%), 10 tahun sebesar 49 subjek (31.2\%), 11 tahun sebesar 41 subjek (26.1\%), dan usia 12 tahun sebesar 14 subjek $(8.9 \%)$.

Tabel 1. Karakteristik Subjek Penelitian Anak Usia Sekolah Dasar di SD Budya Wacana Yogykarta

\begin{tabular}{|c|c|c|c|}
\hline Karakteristik & Keterangan & Jumlah (n) & Presentase (\%) \\
\hline \multirow{2}{*}{ Jenis Kelamin } & Laki-laki & 68 subjek & $43.3 \%$ \\
\hline & Perempuan & 89 subjek & $56.7 \%$ \\
\hline Total & & 157 subjek & $100 \%$ \\
\hline \multirow[t]{5}{*}{ Usia } & 8 tahun & 2 subjek & $1.3 . \%$ \\
\hline & 9 tahun & 51 subjek & $32.5 \%$ \\
\hline & 10 tahun & 49 subjek & $31.2 \%$ \\
\hline & 11 tahun & 41 subjek & $26.1 \%$ \\
\hline & 12 tahun & 14 subjek & $8.9 \%$ \\
\hline Total & & 157 subjek & $100 \%$ \\
\hline \multirow[t]{2}{*}{ Kebiasaan Sarapan } & $\begin{array}{l}\text { Tidak Terbiasa } \\
\text { Sarapan }\end{array}$ & 48 subjek & $69.4 \%$ \\
\hline & Terbiasa Sarapan & 109 subjek & $30.6 \%$ \\
\hline Total & & 157 subjek & $100 \%$ \\
\hline Tingkat Kebugaran & Baik & 0 subjek & $0 \%$ \\
\hline \multirow{2}{*}{ Jasmani } & Cukup & 30 subjek & $19.1 \%$ \\
\hline & Kurang & 127 subjek & $80.9 \%$ \\
\hline Total & & 157 subjek & $100 \%$ \\
\hline \multirow[t]{5}{*}{ Status Gizi } & Sangat Kurus & 2 subjek & $1.3 \%$ \\
\hline & Kurus & 3 subjek & $1.9 \%$ \\
\hline & Normal & 74 subjek & $47.1 \%$ \\
\hline & Gemuk & 38 subjek & $24.2 \%$ \\
\hline & Obesitas & 40 subjek & $25.5 \%$ \\
\hline Total & & 157 subjek & $100 \%$ \\
\hline \multirow{2}{*}{$\begin{array}{l}\text { Penyakit } \\
\text { Kardiovaskular dan } \\
\text { respirasi }\end{array}$} & Tidak & 139 subjek & $88.5 \%$ \\
\hline & $\mathrm{Ya}$ & 18 subjek & $11.5 \%$ \\
\hline Total & & 157 subjek & $100 \%$ \\
\hline
\end{tabular}

Karakteristik kebiasaan sarapan pada subjek penelitian didapatkan frekuensi sebesar 109 subjek (69.4\%) sedangkan yang tidak terbiasa sarapan sebesar 48 subjek (30.6\%). Pada tingkat kebugaran jasmani dapat dilihat bahwa tingkat kebugaran jasmani tertinggi adalah kategori kurang sebesar 127 subjek (80.9\%), sedangkan kategori cukup 30 subjek (19.1\%) dan kategori baik 0 subjek $(0 \%)$. Frekuensi karakteristik status gizi pada subjek penelitian didapatkan pada kategori sangat kurus 2 subjek (1.3\%), kategori kurus 3 subjek (1.9\%), kategori normal 74 subjek (47.1\%), kategori gemuk 38 subjek (24.2\%), dan kategori obesitas 40 subjek (25.5\%). Frekuensi subjek penelitian yang memiliki penyakit kardiovaskular respirasi sebesar 18 subjek (11.5\%) sedangkan yang tidak memiliki penyakit kardiovaskular respirasi sebesar 139 subjek (88.5\%). 
Tabel 2. Hasil Analisis Hubungan Jenis Kelamin, Usia, dan Penyakit Kardiovaskular Respirasi Terhadap Tingkat Kebugaran Jasmani

\begin{tabular}{|c|c|c|c|c|c|c|}
\hline \multicolumn{2}{|c|}{ Variabel Bebas } & \multicolumn{2}{|c|}{$\begin{array}{l}\text { Kebugaran } \\
\text { Jasmani }\end{array}$} & \multirow{2}{*}{$\begin{array}{l}\text { Sig } 2 \\
\text { tailed }(p- \\
\text { value })\end{array}$} & \multirow{2}{*}{$\begin{array}{l}\text { Koefisien } \\
\text { korelasi } \\
\text { (R) }\end{array}$} & \multirow[t]{2}{*}{$\begin{array}{l}\text { Odds } \\
\text { Ratio }\end{array}$} \\
\hline & & Kurang & Cukup & & & \\
\hline \multirow[t]{2}{*}{ Jenis Kelamin } & Laki-laki & 54 & 14 & 0.682 & -0.033 & 0.845 \\
\hline & Perempuan & 73 & 16 & & & \\
\hline \multirow[t]{5}{*}{ Usia } & 8 tahun & 1 & 1 & 0.795 & 0.021 & \\
\hline & 9 tahun & 42 & 9 & & & \\
\hline & 10 tahun & 42 & 7 & & & \\
\hline & 11 tahun & 29 & 12 & & & \\
\hline & 12 tahun & 13 & 1 & & & \\
\hline \multirow{2}{*}{$\begin{array}{l}\text { Penyakit } \\
\text { Kardiovask - } \\
\text { ular Respirasi }\end{array}$} & $\mathrm{Ya}$ & 15 & 3 & 0.781 & 0.022 & 1.205 \\
\hline & Tidak & 112 & 27 & & & \\
\hline \multicolumn{2}{|c|}{$\begin{array}{l}\text { Berdasarkan tabel } 2 \\
\text { kelamin, usia, dan } \\
\text { kardiovaskular respirasi } \\
\text { nilai } p>0.05 \text {, yang artinya ti }\end{array}$} & $\begin{array}{r}\text { pada jer } \\
\text { penya } \\
\text { didapatk } \\
\text { lak terdar }\end{array}$ & & $\begin{array}{l}\text { kelamin }(p= \\
\text { penyakit } \\
(\mathrm{p}=0.781) \mathrm{t} \\
\text { jasmani. }\end{array}$ & $\begin{array}{l}\text { 682), usia } \\
\text { ardiovasku } \\
\text { hadap ting }\end{array}$ & $\begin{array}{lr}=0.021 \\
\text { ir } & \text { re } \\
\text { at } & \text { keb }\end{array}$ \\
\hline
\end{tabular}

hubungan yang signifikan antara jenis

Tabel 3. Hasil Analisis Hubungan Kebiasaan Sarapan, dan Status Gizi Terhadap Tingkat Kebugaran Jasmani

\begin{tabular}{|c|c|c|c|c|c|c|}
\hline \multicolumn{2}{|c|}{ Variabel Bebas } & \multicolumn{2}{|c|}{ Kebugaran Jasmani } & \multirow{2}{*}{$\begin{array}{l}\text { Sig } 2 \\
\text { tailed }(p- \\
\text { value })\end{array}$} & \multirow{2}{*}{$\begin{array}{l}\text { Koefisien } \\
\text { korelasi } \\
\text { (R) }\end{array}$} & \multirow{2}{*}{$\begin{array}{l}\text { Odds } \\
\text { Ratio }\end{array}$} \\
\hline & & Kurang & Cukup & & & \\
\hline \multirow{3}{*}{$\begin{array}{l}\text { Kebiasaan } \\
\text { Sarapan }\end{array}$} & Tidak & 44 & 4 & \multirow[t]{3}{*}{$0.023^{*}$} & \multirow[t]{3}{*}{0.182} & \multirow[t]{3}{*}{3.446} \\
\hline & $\begin{array}{l}\text { Terbiasa } \\
\text { Sarapan }\end{array}$ & & & & & \\
\hline & $\begin{array}{l}\text { Terbiasa } \\
\text { Sarapan }\end{array}$ & 83 & 26 & & & \\
\hline \multirow[t]{2}{*}{ Status Gizi } & $\begin{array}{l}\text { Tidak } \\
\text { Normal }\end{array}$ & 76 & 7 & \multirow[t]{2}{*}{$0.000^{*}$} & \multirow[t]{2}{*}{0.288} & \multirow[t]{2}{*}{4.896} \\
\hline & Normal & 51 & 23 & & & \\
\hline \multicolumn{4}{|c|}{$\begin{array}{l}\text { Berdasarkan tabel } 3 \text { pada analisis } \\
\text { bivariat kebiasaan sarapan dan status } \\
\text { gizi didapatkan nilai } \mathrm{p}<0.05 \text {, artinya } \\
\text { terdapat hubungan yang signifikan }\end{array}$} & \multicolumn{3}{|c|}{$\begin{array}{l}\text { antara kebiasaan sarapan }(\mathrm{p}=0.023 ; \mathrm{R}= \\
0.182 ; \quad \mathrm{OR}=3.446) \text { dan status gizi } \\
(\mathrm{p}=0.000 ; \quad \mathrm{R}=0.288 ; \quad \mathrm{OR}=4.896) \\
\text { terhadan tingkat kebugaran iasmani }\end{array}$} \\
\hline
\end{tabular}

Tabel 4. Hasil Analisis Multivariat Kebiasaan Sarapan dan Status Gizi terhadap Tingkat Kebugaran Jasmani

\begin{tabular}{lll}
\hline & \multicolumn{2}{l}{ Tingkat Kebugaran Jasmani } \\
& p-value & $\mathrm{R}^{2}$ \\
\hline Kebiasaan Sarapan & 0.011 & 0.119 \\
Status Gizi & 0.000 & \\
\hline
\end{tabular}


Berdasarkan tabel 4 kebiasaan sarapan memiliki nilai signifikan yaitu 0.011 dan pada status gizi didapatkan nilai p-value yaitu 0.000 . Didapatkan $\mathrm{R}^{2}$ yaitu 0.119 atau $11,9 \%$ tingkat kebugaran jasmani dipengaruhi oleh kebiasaan sarapan dan status gizi.

\section{PEMBAHASAN}

Hasil penelitian ini menunjukkan bahwa tidak adanya hubungan yang signifikan antara jenis kelamin, usia, dan penyakit kardiovaskular respirasi terhadap tingkat kebugaran jasmani. Komposisi tubuh, kekuatan otot, jumlah hemoglobin pada laki-laki dan perempuan akan berbeda. Volume oksigen maksimal (VO2max) lebih besar pada laki-laki dibandingkan perempuan. Terlebih setelah melewati masa pubertas daya kardiorespirasi laki-laki dan perempuan semakin nampak berbeda. ${ }^{4}$ Seiring bertambahnya umur daya tahan kardiovaskular akan menurun namun penurunan tersebut dapat diminimalisir apabila seseorang melakukan olahraga secara teratur. Peningkatan kebugaran jasmani maksimal hanya akan mencapai diusia 25-30 tahun. ${ }^{5}$ Daya tahan kardiovaskular dan respirasi berperan penting dalam tingkat kebugaran jasmani. Jantung paru serta pembuluh darah harus berfungsi dengan baik, sehingga oksigen dapat masuk kedalam paru hingga ke darah. Dalam proses penyampaian oksigen ke jaringan, jumlah sel darah merah harus normal serta pembuluh darah juga perlu berfungsi dengan normal agar oksigen maksimal dapat disebarkan ke jaringanjaringan terutama otot. Apabila terdapat gangguan fungsi pada jantung dan paru maka dapat menyebabkan penurunan VO2max. ${ }^{6}$

Hasil penelitian dengan analisis bivariat menunjukkan terdapat hubungan antara kebiasaan sarapan dengan tingkat kebugaran jasmani. Anak yang melewatkan waktu makan akan lebih mudah lelah dalam melakukan aktivitas fisik karena kekurangan zat gizi yang cukup. Asupan gizi yang cukup akan membantu tubuh dalam kondisi yang baik sehingga mampu mempertahankan kebugaran jasmani seseorang dengan aktivitas fisik secara teratur. ${ }^{5}$ Sarapan yang mengandung karbohidrat, protein, lemak akan memberikan energi yang digunakan sebagai bahan bakar tubuh untuk digunakan segera dengan aktivitas fisik. ${ }^{7}$

Dalam analisis hubungan status gizi juga didapatkan hubungan yang signifikan dengan tingkat kebugaran jasmani. Status gizi berkaitan dengan pemenuhan kebutuhan zat gizi bagi tubuh. Saat pemenuhan zat tercukupi, maka tubuh akan menggunakannya zat gizi menjadi energi sebagai penggerak jasmani. Sehingga apabila seseorang memiliki status gizi yang baik maka tingkat kebugaran jasmani akan baik pula, hal ini dikarenakan tubuh memiliki energi yang cukup untuk melakukan aktivitas tanpa rasa lelah. ${ }^{8}$ Namun perbedaan hasil penelitian menunjukkan bahwa meskipun status gizi seseorang dikatakan normal namun tidak pernah melakukan aktivitas fisik secara terstruktur dan teratur maka tingkat kebugaran jasmani belum tentu baik. ${ }^{9}$ Pada analisis multivariat sejalan dengan penelitian lain dimana tingkat konsentrasi, stres yang baik, serta produktivitas dalam aktivitas fisik dipengaruhi oleh rutinitas sarapan serta status gizi. ${ }^{10}$ Dalam penelitian ini $11.9 \%$ tingkat kebugaran jasmani anak usia sekolah dasar dipengaruhi oleh status gizi dan kebiasaan sarapan, sedangkan $88.1 \%$ dipengaruhi oleh faktor lain seperti usia, jenis kelamin, adanya penyakit kardiovaskular dan respirasi, aktivitas fisik, manajemen stress, kebiasaan konsumsi alkohol, serta genetik dan lingkungan.

\section{SIMPULAN}

Terdapatnya hubungan yang searah dan sangat lemah antara kebiasaan sarapan 
dengan tingkat kebugaran jasmani. Selain kebiasaan sarapan faktor lain yang juga memengaruhi tingkat kebugaran jasmani yaitu status gizi.

\section{UCAPAN TERIMAKASIH}

Kepada Tuhan yang Maha Esa, SD Budya Wacana Yogyakarta serta tim TPA UKDW untuk ketersediaan dan kerjasamanya sehingga penelitian ini bisa berlangsung dengan lancar.

\section{DAFTAR RUJUKAN}

1. Hoppert Hodgkin, D., 2012. Physiology and Fitness. Virginia: The Great Courses.

2. Porter, S., 2016. Healthy Breakfast. Birmingham: The British Dietetic Association (BDA).

3. KEMENKES, 2014. Pedoman Gizi Seimbang, Jakarta: Direktorat Jenderal Bina Gizi, Kementrian Kesehatan RI.

4. Sulistiono, A. A., 2014. Kebugaran Jasmani Siswa Pendidikan Dasar dan Menengah di Jawa Barat. Jawa Barat: Puslitjak, Balitbang-Kemdikbud.

5. Arifin, Z., 2018. Pengaruh Latihan Senam Kebugaran Jasmani (SKJ) Terhadap Tingkat Kebugaran Siswa
Kelas V di MIN Donomulyo Kabupaten Malang. Malang: AL-MUDARRIS.

6. Febriana, H., 2006. Studi Tentang Tingkat Kebugaran Jantung-Paru Pada Lansia Anggota Klub Jantung Sehat Surakarta tahun 2006. Surakarta: UNSFKIP Jurusan Pendidikan Olahraga dan Kesehatan.

7. Fahey, T. D., Insel, P. M. \& Roth, W. T., 2011. Fit \& well : core concepts and labs in physical fitness. 9 ed. New York: McGraw-Hill.

8. Anggraeni, R., 2016. Hubungan Status Gizi Dengan Tingkat Kebugaran Jasmani Siswa Putra Kelas II di SMP Negeri 3 Jati Agung Lampung Selatan Tahun Ajaran 2016/2017. Bandar Lampung: Fakultas Keguruan dan Ilmu Pendidikan Universitas Lampung.

9. Ramadhana, M. M. L. \& Prihanto, J. B., 2016. Hubungan Antara Status Gizi Dengan Tingkat Kebugaran Jasmani Siswa di SMA Negeri Plandaan Jombang. Surabaya: Jurnal Pendidikan Olahraga dan Kesehatan UNESA.

10. Hartoyo, E., Sholihah, Q., Fauzia, R. \& Rachmah, D. N., 2015. Sarapan Pagi dan Produktivitas. 1st edition ed. Malang: UB Press. 